\title{
CULTURAL PERFORMANCE AS STRATEGIC ESSENTIALISM: NEGOTIATING INDIANNESS IN A WESTERN CANADIAN RODEO FES T IVAL
}

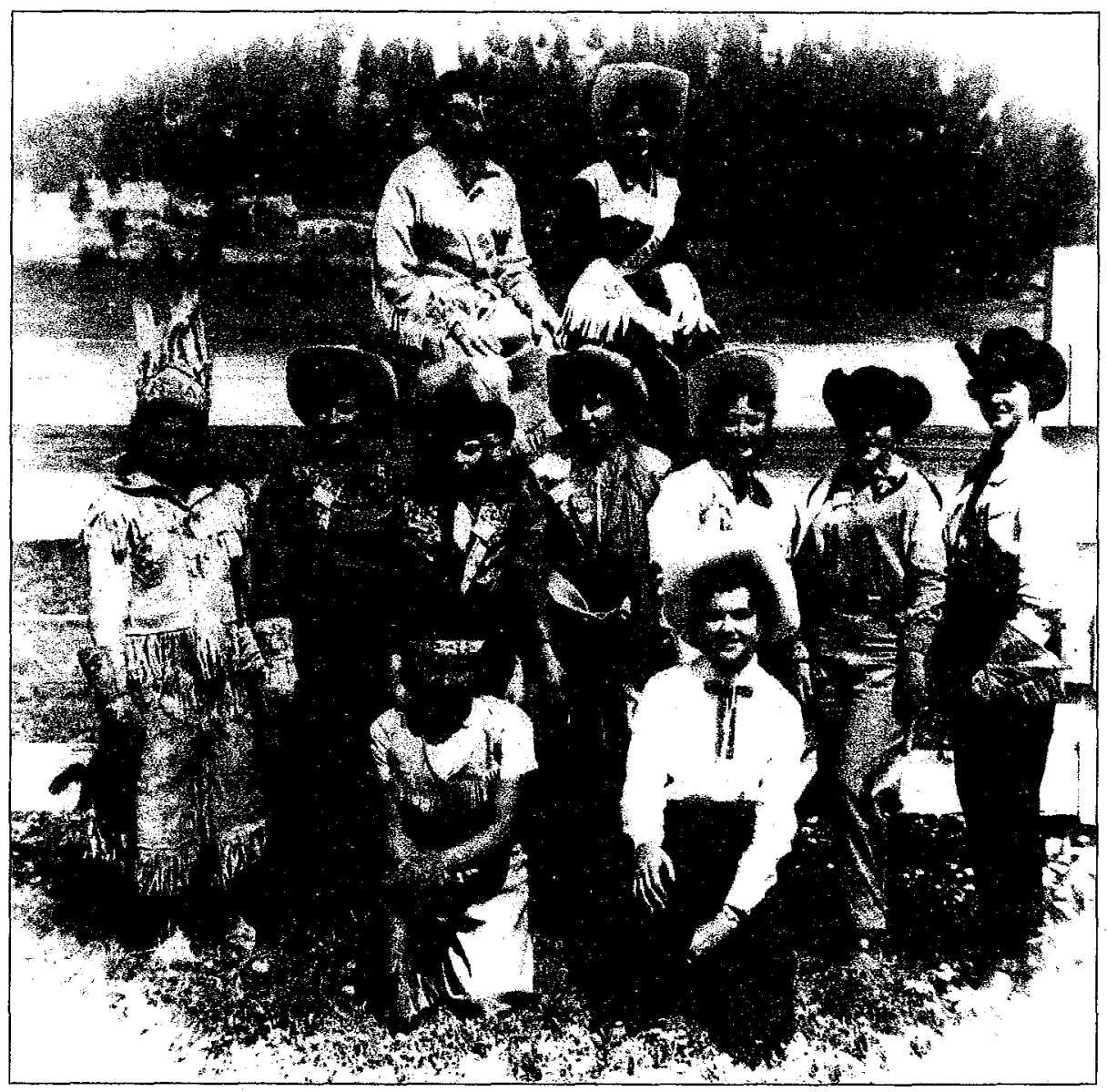

Contestants for the Indian and White Stampede Queen titles, Williams Lake, British Columbia, 1958

The efforts of First Nations leaders in

Canada to remodel their relationship with the Canadian state through court challenges, amendments to the Indian Act, and an overhaul of the Indian Affairs bureaucracy recently have drawn much media and public attention. Yet the politics of colonialism are not limited to national corridors of power, nor are they limited to challenges to the institutional, legal and political/economic structures constraining aboriginal lives. Rather, they are also part of the very fabric of everyday social relations in small cities and towns across rural Canada. This is particularly true in British Columbia, where, after over 
a hundred years of denying the existence of aboriginal title, the provincial and federal governments are now negotiating treaty settlements with First Nations. In many of the rural forestry communities there is a growing concern with the potential social and economic impacts of aboriginal treaties, and the issues of aboriginal rights, self-government, and the future of aboriginal/non-aboriginal relations are widely - and often heatedly-debated in coffee-shops, in public meetings and in community newspapers. In this context, First Nations leaders are striving to gain public support for aboriginal rights and treaties by challenging some of the fundamental assumptions of the dominant EuroCanadian culture. They are questioning the widespread understandings of history and identity that have underpinned, and legitimated, the colonial process: the frontier histories that erase aboriginal people while celebrating the settlers' 'discovery' and 'conquest' of the empty wilderness; the demeaning stereotypes of aboriginality that deny people their individuality and moral integrity, and that encourage some to argue that aboriginal people simply 'don't deserve' treaty settlements.'

This paper addresses one of the multitude of strategies that First Nations leaders in one rural British Columbia community are employing to negotiate issues of identity and history with local Euro-Canadian residents. ${ }^{2}$ This is the strategy of cultural performance: the staged public displays of aboriginal cultural identity. Cultural performances, to be sure, have become central to the language of aboriginal politics. From testimony presented to the Canadian courts during aboriginal title cases to the actions of aboriginal protesters at sit-ins and roadblocks, the symbolic language of political protest all makes use of what has been called 'ethnodrama': 3 the dramatization of cultural symbols of Indianness for political gain. The particular performance I examine here, though, occurs not on ground controlled by aboriginal peoples, but in the overarching context of an annual summer festival that commemorates the history of one rural city in the province's interior region.

Furthermore, this annual festival not only is controlled by a Euro-Canadian organizing committee, but it dramatically celebrates the colonial process itself: the festival pays tribute to the region's . ranching and rodeo heritage, the 'taming' of the Wild West and the conquest of the British Columbia frontier, all processes that required the dispossession of aboriginal territories and the subjugation of the region's aboriginal peoples.

The Williams Lake Stampede is the most important tourist event of the year. During the four-day event the city transforms itself into an imagined Wild West settlement. Businesses and stores remodel their interiors into make-believe Western saloons, hotels and stables, while images of cowboys, Indians, horses and hay bales adorn store windows. There is a specific 
slot assigned to aboriginal people: they are encouraged to participate as culturally exotic 'Indians', to enter the parade on horseback in traditional regalia, to put up arts and crafts booths and tipi villages on the rodeo grounds, and to stage displays of drumming and powwow dancing. The incorporation of aboriginal people into this Western frontier myth provides a mirror image through which the identity of the city is refracted and celebrated. Indian participation symbolically completes the script of colonial history being commemorated through the festival's events.

In the following pages I explore two issues. First, I trace the history of aboriginal participation in the Williams Lake Stampede and the ways in which aboriginal people have adopted the dramatic roles assigned to them in this festival of frontier history. I want to examine what Rayna Green sees as the apparent (and somewhat paradoxical) willingness of aboriginal people in North America to 'play Indian' in colonial dramatizations of history. 4 A historical perspective on this festival reveals a core ritual complex that has persisted for seven decades. This ritual complex imposes limits on the symbolic resources available to aboriginal people, who-within the context of this festival - are seeking to negotiate issues of identity with nonaboriginal people.

Second, I discuss the dilemma that area First Nations leaders face today in contemplating whether or not to become involved in the Stampede festivities. I shift from a theoretical model approaching cultural performance as text to one highlighting performance as social action, and examine how various groups involved in the festival's events are engaging in struggles over the constitution of public identities and over the meaning of performances. I ask: how do area First Nations leaders interpret the benefits and pitfalls of performing Indianness in the overarching context of a Euro-Canadiancontrolled and operated festival? Why are they choosing to adopt what appear to be colonial stereotypes of Indianness in order to present themselves to non-aboriginal audiences? My goal is not to deny the hegemonic power of colonial symbols, or as recent critics of resistance studies have put it, to romanticize resistance to the point where power, domination and the ambiguities of aboriginal responses to colonialism are rendered invisible. ${ }^{5}$ Instead, my intent is simply to create an ethnographic space for understanding the strategic logic of First Nations leaders who, far from naive about the hegemony of colonial stereotypes, are attempting nevertheless to transform cultural performances into vehicles of political power.

OVERVIEW: FIRST NATYONS AND WILLIAMS LAKE

Williams Lake lies some five hundred kilometers north of Vancouver in the Cariboo-Chilcotin region of the British Columbia interior. The forest industry 
forms the base of the regional economy,

although ranching, mining, and

government employment are also

important. The city has a population of

about ten thousand, but serves as the main commercial and administrative center for a much wider regional population of sixty thousand. Rural families regularly travel to the city to buy groceries, clothing, hardware and livestock supplies, and to obtain medical and government services. Included in the regional population are fifteen Secwepemc, Tsilhqot'in and Carrier First Nation reserve communities, totalling about six thousand registered band members. Aboriginal people therefore comprise at least io to i5 per cent of the regional population.

The non-aboriginal population of Williams Lake has prospered greatly since the expansion of the forest industry in the I $95^{\circ}$ s. Many people are employed directly by the local mills as mill workers, truckers or contract loggers, or are employed indirectly through businesses such as machine repair shops and heavy equipment suppliers that provide the mills with goods and services. In contrast, aboriginal people in the Cariboo-Chilcotin over the last four decades have been largely excluded from employment as the forest industry and infrastructure of businesses, services and government agencies have grown and prospered. Their marginalization has been exacerbated by dependency on welfare and the extensive restrictions imposed by the Indian Act, the Indian reserve system and the coercive policies of the federal Department of Indian Affairs. With the provincial and federal governments now engaged in treaty negotiations with a number of First Nations, the economic marginalization of aboriginal people is now beginning to shift. Many First Nations are beginning to . establish relationships with government ministries, forest companies and local businesses, all of whom are anticipating a future in which First Nations will be in control of significant resources and will be important players in the regional economy.

At an everyday level, though, aboriginal relations with Euro-Canadian townspeople remain fraught with tension. While there is a public awareness of the importance of the values of multiculturalism and tolerance, racial prejudice and discrimination against aboriginal people are still evident both in the subtle gestures and the openly demeaning insults and behaviours that aboriginal people may be subjected to in the school yards, stores and pubs around town. Aboriginal and non-aboriginal people may occupy the same public spaces-the fast-food outlets, the grocery stores, the bingo halls, the recreational sports venues. But an implicit convention of mutual avoidance tends to reduce social interaction between aboriginal and nonaboriginal people. They occupy relatively separate social worlds.

This social isolation is enhanced by the geographic isolation of reserve communities of the region. While 
aboriginal people move freely between their reserves and the city, a similar movement among non-aboriginal people does not occur. Few non-aboriginal people, it seems, have visited reserve communities, and many seem to be unaware even of the names or locations of the different reserves. Indian reserves are invisible to non-aboriginal people except in the abstract: they are imagined as dangerous, foreign and violent places where non-aboriginal people are not welcome. The cultural life of reserve communities, and the cultural differences among the Secwepemc, Carrier and Tsilhqot' in people, also remain largely invisible.

In this context, one of the major tasks facing area First Nations leaders in attempting to advance claims to aboriginal title and rights and to develop more positive, respectful relations with nonaboriginal people, is that of initiating a meaningful dialogue. How might this dialogue begin? How can First Nations begin to challenge the negative identities they are often ascribed-the stereotypes of the 'drunken Indian', the 'Indian criminal', the 'lazy Indian living off government handouts? How can First Nations leaders create a more positive climate for the education of their children in the local schools, for the treatment of aboriginal people within the justice system, or merely for the way aboriginal people are viewed in the public spaces in Williams Lake? Area First Nations leaders are employing a variety of strategies.
Cultural performance, and particularly the very public, positive expresssion of Indianness within the Stampede festival, is one strategy they are contemplating.

\section{THE HISTORY OF THE STAMPEDE}

The Williams Lake Stampede originated in I9I9, the year the settlement of Williams Lake was officially born. By the rg2os the Stampede had become a popular annual event attended not only by village residents but by tourists, area ranchers, and Secwepemc, Tsilhqot'in and Carrier people. The Stampede included several events now commonly associated with rodeo: roping competitions, bull and bronc riding events, and horse races. The Stampede, though, was not a purely local invention. It consisted of a ritual complex adopted from the Wild West exhibitions that originated in the United States in the I88os and that, through the entrepreneurial skills of Buffalo Bill Cody, evolved into major entertainment spectacles shown to enthusiastic audiences throughout North America and Europe. ${ }^{6}$ This ritual genre very quickly spread to small town festivals and fairs across North America, from the wellknown Calgary Stampede and Cheyenne Frontier Days to the smaller agricultural fairs and exhibitions across the Canadian and American plains. ${ }^{7}$

The core events of Buffalo Bill's Wild West exhibitions were the demonstrations of cowboy skills of roping and trick riding, demonstrations that eventually evolved into contemporary rodeo. But it was their 
dramatic reenactments of scenarios from the history of the Western frontier that captured the audience's attention and imagination. These reenactments included displays of a presumably static, 'pre-contact' Indian life-tipi villages, Indian dancing-as well as reenactments of Indian-white conflict on the frontier:

Indian attacks on stagecoaches and settlers' cabins. Together, they presented narratives of the frontier myth of history, telling the story of the heroic encounter of whites and Indians on the frontier, the ultimate triumph of white settlement and conquest, and the regrettable but inevitable disappearance of Native people in the wake of progress and civilization. ${ }^{8}$

In Williams Lake, this ritual genre laid the foundation for the early Stampedes. Rodeo contests remained the central events. But in the rg2os a series of dramatic performances and contests were included that highlighted the frontier themes and Indian-white contrasts. Some novelty races were for Indians only. The 'Indian Race' of I924 required participants to wear 'war bonnets'. In 1926, the Stampede program promised that spectators would be treated to displays of 'Indians dancing in their old-time costumes'. At the same time, the ritual complex was adapted to the regional setting. The famous Wild West scene of the Indian attack on a stagecoach was Canadianized: the 1924 program promised audiences would witness an Indian attack on a Hudson's Bay fort.
Over the next three decades the Stampede remained the most popular annual gathering for townspeople, area ranchers and aboriginal people alike. Over time, some events wैere modified and new ones added. By the I950s, the local economy was booming and the population surging. There was efflorescence of popular cultural representations of the "noble savage' in Hollywood westerns and television programs. At the same time, there was a new. awareness of the dangers of racism, brought to international attention through the horrors of the Nazi Holocaust. In this context, the Stampedes of the r 95 os enacted new rituals of community identity through which Indians and whites were represented as existing in a balanced, harmonious relationship. While the dramatic performances of frontier conflict were dropped, the displays of Indian culture, Indian people and the Indian-white dichotomy remained central. In $195^{\circ}$, the colonial eategories of Indian and white were elevated to new heights of reification with the modification of the Stampede queen contest to include both an Indian and a white queen. At the coronation ceremonies the Indian and white queens sat on matched thrones, the Indian queen in decorated buckskin and feathered headband, the white queen in a white satin gown and tiara. This image of a balanced, harmonious relationship contrasted sharply with the realities of ongoing racial discrimination and the conventional banning of aboriginal people from the hotels and restaurants around town. 
In the I 960 s climate of civil rights protests and increased movements towards racial integration, organizers of the Stampede decided to amalgamate the Indian and white queen contests into one. But the duality of the Indian/white archetype was preserved in other aspects. Aboriginal people, dressed in buckskin and regalia, continued to enter the Stampede parade. Secwepemc, Carrier and Tsilhqot'in families from across the Cariboo-Chilcotin travelled to the Stampede in horse-drawn wagons, setting up their canvas tents on the Stampede grounds where they remained for the week, visiting with friends and relatives and celebrating an intertribal community that largely excluded Euro-Canadian townspeople. Nevertheless, the 'Indian Camp', as it was known to non-aboriginal people, became a spectacle of tourist interest and curiosity, preserved in tourist snapshots, artists' paintings and souvenir postcards.

By the I970s and I 980 s the increased politicization of the regional aboriginal communities, and their struggles to address the many dimensions of political, economic and bureaucratic domination they experienced, led inevitably to public debates about the role of aboriginal people in the Williams Lake Stampede.

Aboriginal people were voicing resentment at being assigned roles of noble savages and being economically exploited as tourist attractions. Yet, at the same time, area aboriginal people were also undergoing a cultural revitalization that involved not only a revival of
Secwepemc, Carrier and Tsilhqot'in traditions, but also an incorporation of significant components of Pan Indian cultural practices of powwows, drumming, dancing and sweatlodge ceremonies. These cultural traditions increasingly served as a currency for aboriginal people to communicate to themselves, and to non-aboriginal audiences, the distinctiveness of aboriginal cultural and political identities. The symbols of culture that had long been part of the ritual complex of the Stampede - that could be read as reaffirming the colonial project-were revitalized as symbols of political power for the advancement of aboriginal interests and agendas. The political contest ultimately was not over the symbols themselves-feathered headbands, decorated buckskin, and powwow dances - but over their significance and meaning, and over how these symbols of cultural identity were to be read and comprehended by the general public.

In short, for almost eight decades the Stampede has served as the major occasion for the ritual performance of Williams Lake's collective identity as a frontier town, an identity performed not only for local residents but for tourists and visiting dignitaries alike. Throughout its history there has been a consistent ritual core. What began as historical reenactments of the imagined confrontation of Indians and settlers on the frontier evolved into symbolic displays 
of the Indian-white dichotomy. The

Indian-white juxtaposition became an archetype in the construction of the town's public identity and history; and this archetype, and the frontier history in which it is embedded, continue to provide the major symbols of public identification in the city today.

But why have Secwepemc, Carrier and Tsilhqot'in people willingly participated in the Stampede for over seven decades?

Many anthropological studies of cultural performances-of rodeo, ${ }^{9}$ parades,${ }^{10}$ and small town festivals" - take a 'textualist' analytical approach. The observer reads these performances for their inherent meaning, arguing that cultural performances convey deep cultural themes, play with inherent contradictions in the social order, and project images of community solidarity that mask social conflict, domination and inequality. In this context, the Stampede, like all small town festivals, can be read as a narrative performance of the town's myths of history and public ideology. 'Textualist' approaches often make assertions about the function of cultural performances, arguing that the participation of subordinate groups only reinforces their perhaps unwitting compliance with the systems of inequality that have rendered them powerless.

Yet this theoretical perspective cannot account for the willingness of subordinate groups to participate in rituals of the dominant. ${ }^{12}$ Instead, cultural performances can also be approached as forms of social action, where participants themselves have various understandings of the meanings of ritual events, and where these events become the occasion for contesting dominant ideologies and creating new, politicized identities of the subordinate..$^{13}$ What may appear to be a submission to colonial stereotypes, and what may appear to be instances of aboriginal people 'playing Indian', emerge from a lack of appreciation for the multiple meanings at play in ritual contexts, and the way in which aboriginal people have long been engaging in cultural performance not only to express aboriginal meanings and identities, but also to subvert and challenge dominant stereotypes of Indianness.

The remaining question, then, is: how do various First Nations people of the region view the advantages and disadvantages of performing culture in the context of the Stampede festival?

\section{THE STAMPEDE TODAY}

The Williams Lake Stampede is held every summer over the I July weekend. The centrepiece of the festival is the professional rodeo, but there are many other events to entertain children, their families and visitors to the city. Pancake breakfasts and steak dinners are held in the grocery-store parking lots. A midway, with rides and games of chance, is set up outside the rodeo grounds: The annual parade draws huge crowds to the downtown streets. There are sidewalk sales, children's amusements, and musical 
groups playing in the city's parks. The Stampede provides a major source of revenue to city businesses. One retailer referred to the Stampede period as a 'Cowboy Christmas', the second most important time of the year for retail sales. The Chamber of Commerce unofficially estimates that the Stampede brings in almost one million dollars to the city's economy.

The festival itself is run by a non-profit society, the Stampede Association, which is comprised of rodeo enthusiasts, area ranchers and downtown business owners. None of the r 994 board members or the over ninety volunteers who worked on the 1994 Stampede were aboriginal.

Nevertheless, representatives have frequently stated that they would encourage aboriginal involvement. They see Indian participation-the erection of mock Indian villages, the performances of powwow dancing on the rodeo groundsas part of the 'rodeo tradition'. Organizers also realize that aboriginal involvement would be a great tourist attraction, and would economically benefit the Stampede organization and the city as a whole. While recognizing that relations between aboriginal and non-aboriginal people today are 'touchy', they nevertheless feel that area First Nations are 'missing out on an opportunity to market their culture' by failing to get involved in the Stampede festivities. Aboriginal people, however, do participate in the festivities: as rodeo riders, as spectators, as entrants to the parade. Occasionally an aboriginal woman will enter the Stampede Queen contest. But it is the organized displays of Indian culture on the rodeo grounds that the Stampede organizers hope to solicit, and it is these forms of organized display and performance that are now the issues of contention.

Since the I97os aboriginal people in the region have been using a variety of symbols and ritual practices to express and convey their aboriginal identities: Plains Indian-style tipis, feathered head-dresses, buckskin regalia, sweatlodge ceremonies, pipe ceremonies, powwow dancing, and most recently, the Indian princess contests that accompany invitational powwows. In different ways these symbols and rituals of identity are being mobilized as forms of political power for advancing the interests, status and rights of regional First Nations. But these symbols are also subject to variable interpretation. Many of these symbols resonate with the noble savage images of Indianness purveyed through popular cultural representations ranging from Hollywood movies and popular fiction to Boy Scout traditions. Not only may these symbols be interpreted differently by aboriginal and nonaboriginal audiences, there is also significant debate within the various aboriginal communities regarding the legitimacy and meaning of these symbols of identity. I will limit my discussion to the various Secwepemc opinions on this matter, as most of my ethnographic work in the region has been with Secwepemc groups, where I have carried out 
ethnographic and applied research for a number of years since 1985 on topics including community revitalization and Pan-Indianism. ${ }^{14}$ My understanding of Secwepemc perspectives on cultural representation and ceremonialism comes both from my long-term involvement and from interviews conducted with various members of the regional Secwepemc community in the I994-1995 period.

Academic debates regarding the nature of culture-whether we can speak of 'authentic' culture as opposed to 'invented' culture-find their parallel in the ways in which Secwepemc people debate the legitimacy and authenticity of cultural symbols and rituals. Not all Secwepemc people attend powwows or sweatlodge ceremonies. Some individuals dismiss sweatlodge ceremonies, as well as other recently-popular spiritual practices such as the Plains Indian pipe ceremonies and Sun Dances, as 'imported culture'. They argue that these practices are not traditional to the Secwepemc. They see these ceremonies as carrying no meaning, and they worry that those who engage in them are being misled by spiritual leaders of dubious integrity.

Other Secwepemc people find meaning in powwow dances and sweatlodge ceremonies, but they do not personally support the idea of performing such rituals for non-aboriginal audiences. Their concern is not with the legitimacy of cultural symbols of identity, but with the meanings that may be conveyed, and the stereotypes that may be affirmed. Some argue that dressing in Indian regalia and 'parading for whites' is a degrading spectacle. Others argue that conveying identity through these essentialist images ultimately limits the audience's ability to appreciate the full individuality, diversity and humanity of aboriginal people. They voice resentment at the power of the Euro-Canadian festival organizers to control the terms - and the symbols - for their participation in the event.

Remarking on the manner in which EuroCanadians have assigned aboriginal people a status of virtual invisibility in the regional social landscape, one leader remarked in frustration, 'There's room for us as tourist attraetions, but when we want to be human, the door is shut'. Ultimately, these individuals are drawing attention to the fact that the meaning of cultural performance is derived from the broader context of power relations in which nonaboriginal residents still hold privileged control over when aboriginal people will be acknowledged, and on whose terms. At the everyday level of informal social interaction, these terms of recognition often are limited to a restricted range of identities: the 'drunken Indian', the 'Indian criminal', the 'noble savage'.

Mediating these positions are a few First Nations individuals who are willing to act as 'cultural bridges', and who on occasion do coordinate aboriginal cultural performances and displays for nonaboriginal audiences. Among these are elected First Nations chiefs and past chiefs, as well as individuals employed in the 
public service. All, by virtue of their position, have taken on roles of advocacy for aboriginal people in their dealings with non-aboriginal society. In the last few years, for example; these leaders have organized cross-cultural training workshops to introduce the regional police, court workers, judges, social services workers and school teachers to aboriginal cultural beliefs, values and spiritual practices, such as pipe ceremonies and sweatlodge ceremonies. They believe in the potential for such cultural performances to bridge the gap in understanding between the aboriginal and non-aboriginal populations, and to improve the tenor of social relations in the city.

Yet these First Nations leaders also have ambivalent attitudes towards participating in the Stampede festivities as adjunct sideshows to the larger ritual and where they lack full control over the terms of their participation. They share a strong conviction that Stampede organization, and the Williams Lake community generally, take the aboriginal presence for granted, misinterpret cultural performances, and benefit economically from displays of aboriginal heritage while returning little to the reserve communities. One individual commented:

What I want to know is: what is Williams Lake willing to put in? Let's talk money! The Stampede has been commercialized now. It's a money-making thing. We want to benefit too ... The town of Williams Lake doesn't do nothing for [our] Band. We spend between
\$100,000 and $\$ 120,000$ every month in town, in the local businesses ... and the town doesn't do nothing for us!

These leaders are concerned with being spatially marginalized during the Stampede festivities: of being sequestered into a small space and being forced into secondary roles that diminish the importance of aboriginal culture. One individual saw these issues in a deeper historical context, arguing that the history of aboriginal involvement in the Stampede is a history in which EuroCanadians have controlled the terms of aboriginal participation, including and excluding them when convenient. The most controversial event, and one still resented today by those area aboriginal people who remember the earlier Stampedes, was the Stampede Association's decision in the ig7os to charge aboriginal people for camping on the grounds. In earlier times, the fact that aboriginal people camped on the grounds and were allowed into the rodeo for free was taken as a sign of Euro-Canadian recognition that the Stampede grounds were located on aboriginal traditional territory. With the policy shifts of the r97os, aboriginal people were 'pushed out' of the Stampede and their traditional rights were denied. Given this historical context, First Nations leaders see the current tensions with the Stampede organizers as rooted in issues of control:

I don't think they want to see First Nations people empowering themselves. They want to keep control ... Our people have always 
responded to them when they tell our people what to do. But now our people are becoming empowered, so [aboriginal people] don't [respond] ... We do speak up. I think people are very uncomfortable about that.

Despite these concerns, most of these First Nations leaders did express an interest in participating in the Stampede under certain conditions. They were willing to represent cultural identity through a variety of symbols of Indianness: through putting up tipis, setting up booths selling bannock, jarred fruit and crafts, and staging lahal games, powwows and drumming performances. These individuals are not unconcerned with the potential for general audiences to misconstrue the meaning of cultural performances. Their willingness to use these symbols of cultural identity to communicate with non-aboriginal audiences must be understood in the terms of the broader constraints that bear down on their overall ability to negotiate identity in the Cariboo-Chilcotin, and given these limitations, their pragmatic political intentions and their strategic considerations of the dual audiences to whom they are directing their displays and performances.

The hegemony of colonial stereotypes lies not in the symbols themselves, but in the epistemological power exercised by dominant groups to control the meaning of these symbols. As Patrick Wolfe has argued with regard to Australian Aborigines' entanglement within the concepts and language introduced by colonialism, 'to acquire a hegemonic language is to submit to a framework in which local meanings can take on unpredictable significance in relation to oppositions or associations whose determination is independent of local factors'. ${ }^{5}$ When aboriginal people in the Cariboo-Chilcotin engage in powwow drumming, dancing and sweatlodge ceremonies, how individuals experience and imbue these events with meaning is contained within local fields of understanding (although, as I have indicated, these local fields also are heterogeneous). For a number of people, these practices have become the means for expressing deeply rooted feelings of identity, spirituality and belonging. But to non-aboriginal audiences reared on Hollywood movies and pulp Western novels, these practices may take on quite different signification, resonating instead with the stereotypical images of the noble savage that are embedded in popular Canadian culture. At the very least, the manner in which audiences understand and interpret these performances becomes unpredictable when these practices are transported beyond contexts controlled by aboriginal people. The use of such symbols and practices, so easily absorbed into hegemonic constructs of exotic Otherness, does not necessarily contribute to the subjugation and powerlessness of the aboriginal population. What it does mean is that public performances of aboriginality are sites defined by the confrontation of 
multiple epistemologies variously privileged by social fields of power.

Aboriginal people of the CaribooChilcotin are acutely sensitive to the epistemological power of the dominant society: the ability of non-aboriginal people to misconstrue aboriginal behaviours and utterances as evidence for the 'drunken Indian' or the 'Indian criminal' stereotypes; the ability of nonaboriginal politicians and lawyers to misconstrue the history of British Columbia so as to deflect and deny aboriginal rights and title. They are also sensitive to the hegemonic potential of noble savage imagery. Non-aboriginal people, one Tsilhqot'in leader pointed out, frequently overlook the way in which powwows, dancing and drumming embody the most central values of aboriginal societies, treating these performances like a show, an entertainment spectacle, 'like the Shrine Circus'. He continued:

They don't see the importance of our spiritual and cultural values that are exercised through powwows and drumming. The drummers are into their own spirituality for the drum, eh, and the dancers are also into their own spirituality for honouring the great spirit and mother earth. It's not just a cultural show, but there is spirituality involved.

The risk is not only that non-aboriginal audiences will misinterpret these performances. There is also the risk that these performances will be dismissed as inauthentic by some aboriginal people themselves. These leaders, thus, must also negotiate their way through the plural interpretations of cultural performances that may exist among both the regional non-aboriginal and aboriginal populations.

Nevertheless, those I spoke with were not overly concerned with defending the authenticity of these practices. Instead, they responded by adopting a model of culture remarkably similar to those now advocated by contemporary anthropologists, through which notions of a static, bounded, traditional culture have been deconstructed and replaced by a model that highlights the dynamic, creative and fluid nature of cultural systems. This very fluidity, one Secwepemc leader claimed, constitutes aboriginal tradition:
All people from the past have learned to borrow. There has been a lot of borrowing: It's a continuation of that trend from the past. What it does is build on the model, the model style ... If you look at some of our elders, when they dance--that's a borrowed thing. That's been going on for years. See, the other thing too is that we lost a lot of our cultural traditions. It's not what it is today. Yet that's part of ... our people ... searching for identity. And that's what we're taking back from the earth. That's who we're becoming. We're slowly becoming this style. We use whatever it is. We're still.following our traditions.

A similar understanding of tradition was voiced by another Secwepemc leader: 
What else can we do? We've lost everything. We don't have any memory of what we did before ... I think sometimes you get fooled into thinking the only way we can be a true Indian is to live how people did one hundred years ago ... Tradition evolves. It's ongoing every day. It's not something that happened one hundred years ago. People stárt traditions today, and people do, everyday ... And if it doesn't work it disappears. If it does, it gets lodged as tradition ... and that's what we're doing now, saying that some of the things we did then aren't good for us now ... we don't have to keep going as they did.

When engaging in cultural performances, First Nations leaders are aware that they are entering into fields of competing definitions of the very nature of aboriginal culture and tradition.

Despite these endemic risks, most of the leaders I spoke with were willing to consider organizing cultural displays and performances in the overarching context of Stampede festivities. Their motivations had to do with their own pragmatic political concerns, and their assessment of their potential audiences. Further, they were willing to become involved only if they could exercise total control over the terms, conditions and processes through which these performances would be held.

When directed to general audiences, these leaders felt that cultural performances: could only raise the positive public profile of aboriginal people of the region. These individuals are explicitly attempting to counter not only the negative stereotypes of Indianness but the widespread invisibility of aboriginal people to the regional society. Thus, one individual felt that to not participate would be only to further their invisibility to EuroCanadians. '[Aboriginal culture] gets most misunderstood when you don't see anything', he commented. Another leader felt that participating in the Stampede would counteract Euro-Canadian tendencies to only 'see' aboriginal people who conform to their preconceived stereotypes of the 'drunken Indian'. Aboriginal cultural displays 'would be an eye opener for the people of Williams Lake', as people would realize that 'the [aboriginal people] they see on the streets aren't the only ones around'. While these strategies may reflect the degree to which the dominant culture has restricted aboriginal modes of resistance-that aboriginal people have to submit to images of cultural exoticism to capture 'positive' non-aboriginal attentionaboriginal agency has nevertheless survived. Stereotypes of Indianness are being mobilized with an eye to their practical implications: positive images may afford some temporary relief to the continual denial of worth to which aboriginal people are subjected through many forms of everyday racism.

Furthermore, such performances may create a context for people to create and renew positive cultural identities amongst themselves. ${ }^{16}$ First Nations leaders felt strongly that these positive, public 
assertions of Indianness within the context of the Stampede festivities would also be of great benefit to area aboriginal people in boosting their own cultural pride and self-esteem. As one individual remarked:

I think, all of these types of activities [tipis; lahal, fish barbecues, arts and crafts booths] will ... make our young people, and even our older people, be proud of who we are. We need to be very visible. In a positive way.

The fact that these performances would be enacted in the risky setting of a EuroCanadian festival only enhances their political significance. Rather than undermining aboriginal meanings, the public Euro-Canadian festival context transforms these performances into defiant assertions of moral worth and integrity that contrast sharply with the racism that pervades other dimensions of the regional non-aboriginal society. When directed at aboriginal audiences, the question of non-aboriginal audience response becomes irrelevant to these leaders. It is the very juxtaposition of dominant and subordinate constructions of the meaning of aboriginal culture that would empower these performances as modes of resistance to the dominant EuroCanadian culture.

In conclusion, in order to negotiate issues of identity and history with non-aboriginal audiences, First Nations leaders of the Cariboo-Chilcotin must first of all develop a means to command public attention. They must develop a means of counteracting the invisibility they are typically ascribed in many other dimensions of their relationships with non-aboriginal people. In other arenas of political action, First Nations leaders are mobilizing their political (and imminent economic) strength in current provincial treaty policies, and their moral power as victims of racism, in order to challenge various aspects of their relationship with non-aboriginal society. In the ritual context of the Williams Lake Stampede, First Nations individuals are contemplating manipulating the power inherent in the public's fascination with Indian culture, and the centrality of Indians in the Stampede's ritual script, in order to draw attention to issues of cultural pride, power and racism in local social relations. They are making use of the unwitting power they can draw from the 'colonial gaze' in order to begin this process of renegotiating the meaning of aboriginality.

As James Carrier points out, there are dangers inherent in 'ethno-Orientalisms', essentialist representations of aboriginality by aboriginal people themselves. These constructions can 'mislead and have unfortunate consequences if they are applied unreflectively in novel situations' ${ }^{17}$ The danger of these homogeneous representations of Otherness, however, lies not in the representations themselves, but in how these representations are used and their social, political and economic 
consequences. Further, the individuals I interviewed here are not unreflective or naïve, but are experienced players in the contemporary politics of identity. As various scholars of colonialism have argued, strategic essentialisms may be extremely powerful representational strategies for both mobilizing indigenous peoples into collective political action and for advancing their collective political interests in particular historical and political contexts. ${ }^{18}$

But First Nations leaders in the CaribooChilcotin are not rhetorically committed to these essentialisms. In many other contexts aboriginal people are deconstructing essentialist stereotypes and/or are making claims to equality and similarity with other non-aboriginal Canadians through a rhetoric based on drawing 'strategic equivalences' with their non-aboriginal audiences. ${ }^{19}$ In the ritual context, however, by virtue of the power engendered in the colonial category of the Indian, engaging in cultural displays and performances of Indianness is a powerful counter-hegemonic strategy.

First Nations leaders, like anthropologists, at times are concerned with the issues of tradition, authenticity and the hegemony of colonial symbols. In private settings, powwow songs, dancing, sweatlodge ceremonies and other events are providing the means for expressing and experiencing unique identities. Increasingly, these practices and performances are being used as a language to express identity to non-aboriginal audiences. These individuals are concerned with the difficulties of crosscultural translation, and the potential for general audiences to misinterpret cultural performances. The risks of miscommunication, though, are outweighed by the pragmatic political potential that these performances may bring to the enhancement of aboriginal self-pride and the improvement in the state of local social relations. While neither First Nations leaders nor anthropologists can predict with certainty the outcomes of their representations, ${ }^{20}$ it is the intentionality of those agents, and the considerations and forces that guide and constrain their choices of action, that are critical to trace for understanding the continuing, determined efforts of aboriginal people to use 'old' symbols to negotiate new identities and relationships with non-aboriginal audiences. $\curvearrowright$

ELIZABETH FURNISS

Elizabeth Furniss is a Visiting Fellow at the Centre for Cross-Cultural Research at the Australian National University

\section{NOTES}

'This article is a revised version of a chapter of The Burden of History: Colonialism and the frontier myth in a rural Canadian community (University of British Columbia Press, in press, 1999) in which I trace more broadly the contemporary cultural politics of aboriginal/non-aboriginal relations in a rural community in British Columbia. The research and writing of this article were 
supported by doctoral and post-doctoral fellowships from the Canadian Social Sciences and Humanities Research Council and by the Centre for Cross-Cultural Research, Australian National University, where I am currently based.

${ }^{2}$ In formal discourse aboriginal people in British Columbia use the terms First Nations and aboriginal to refer to themselves, and I have followed that usage here. In more informal contexts, people in the Williams Lake region frequently refer to themselves as Native. The terms Indian and white, however, are also commonly used in informal settings. These terms are not self-referential but are used to designate others, but not necessarily with a derogatory connotation. I use the term Indian only rarely, when I am referring to non-aboriginal perspectives on aboriginal people. In this sense, I speak of negotiating Indianness as a public negotiation of the manner in which Euro-Canadian townspeople are to view aboriginal people. Finally, the majority of townspeople in Williams Lake are of European ancestry, and I have used the term Euro-Canadian to designate this group. This term is considered appropriate in formal, academic discourse although it is rarely used in informal discourse in rural towns.

3 Robert Paine, 'Ethnodrama and the "Fourth World": The Saami Action Group in Norway, I979-198r', in Noel Dyck (ed), Indigenous Peoples and the Nation-State: Fourth world politics in Canada, Australia and Norway (St. John's, Nfld.: Institute of Social and Economic Research, Memorial University, I985), pp. $190-9^{\text {I. }}$

4 Rayna Green, "The Tribe Called Wannabee: Playing Indian in America and Europe', Folklore, 9.9.I (1988), 30-55.

5 Lila Abu-Lughod, "The Romance of Resistance: Tracing transformations of power through Bedouin women', American Ethnologist, I7.I (I990), 41-55; Sherry B. Ortner, 'Resistance and the Problem of Ethnographic Refusal', Comparative Studies in Society and History, 37.I (I995), I73-93; Michael F. Brown, 'On Resisting Resistance', American Anthropologist, 98.4 (1996), 729-49.

${ }^{6}$ Don Russell, The Wild West: A history of the wild west shows (N.p.: Forthworth, Texas).

${ }^{7}$ James Gray, A Brand of its Own: The roo year history of the Calgary exhibition and stampede, (Saskatoon: Western Producer Prairie Books, 197o); Mary Lou LeCompte, 'Wild West Frontier Days, Roundups and Stampedes: Rodeo before there was Rodeo', Canadian Journal of History of Sport, $\mathbf{I} 6.2$ $\left(\mathrm{I} 98_{5}\right), 54-67$; Jon Whyte, Indians in the Rockies, (Banff: Altitude Publishing, 1985 ); Keith Regular, 'On Public Display', Alberta History, 34.I (I986), I-Io; Katherine Pettipas, Severing the Ties that Bind: Government repression of indigenous religious ceremonies on the prairies (Winnipeg: University of Manitoba Press; 1994).

${ }^{8}$ Richard Slotkin, Gunfighter Nation: The myth of the frontier in twentieth-century America (New York: Atheneum, 1992), pp. $63-87$.

${ }^{9}$ Beverly Stoeltje, 'Cowboys and Clowns: Rodeo specialists and the ideology of work and play' in Richard Bauman and Roger Abrahams (eds), And Other Neighborly Names', Social Process and Cultural Image in Texas Folklore (Austin: University of Texas Press, 1981), 123$5^{\mathrm{I}}$; Elizabeth Atwood Lawrence, Rodeo: An anthropologist looks at the wild and the tame (Knoxville, Tennessee: University of Tennessee Press, I982); Frederick Errington, 'The Rock Creek Rodeo: Excess and constraint in men's lives', American Ethnologist, 17.4 (199o), 628-45.

${ }^{\text {10 }}$ Carole Farber, 'High, Healthy and Happy: 
Ontario Mythology on Parade', in Frank Manning (ed.), The Celebration of Society: Perspectives on contemporary cultural performance (Bowling Green: Bowling Green University Popular Press, 1983), 33-50; Denise L. Lawrence, 'Rules of Misuse: Notes on the Doo Dah Paradein Pasadena', in Alessandro Falassi (ed.), Time out of Time: Essays on the festival (Albuquerque: University of New Mexico Press, 1987 ), I23-36.

"Robert H. Lavenda, 'Family and Corporation: Celebration in central Minnesota', in Frank Manning (ed.), The Celebration of Society; Frederick Errington, 'Reflexivity Deflected: The festival of nations as an American cultural performance'; American Ethnologist, I $4.4(1987), 654-67$.

${ }^{12}$ See James Scott, Domination and the Arts of Resistance: Hidden transcripts (New Haven: Yale University Press, I99o).

'3 Ronald Grimes, Symbol and Conquest: Public ritual and drama in Santa Fe, New Mexico (Ithaca: Cornell University Press, 1970); Fred R. Myers, 'Culture-Making: Performing aboriginality at the Asia society gallery', American Ethnologist, 21.4 (I994), 679-99 Dorothy C. Holland and Debra G. Skinner, 'Contested Ritual, Contested Femininities: (Re)Forming self and society in a Nepali women's festival',American Ethnologist, 22.2 (I995), 279-3o5; Julie Cruikshank, 'Negotiating with Narrative: Establishing cultural identity at the Yukon international storytelling festival', American Anthropologist, 99.I (I997), 56-69.

${ }^{14}$ Elizabeth Furniss, A Sobriety Movement Among the Shuswap Indians of Alkali Lake,
MA Thesis (University of British Columbia, 1987).

${ }^{15}$ Patrick Wolfe, 'On Being Woken Up: The dreamtime in anthropology and in Australian settler culture', Comparative Studies in Society and History, 33.2 (I991), p. I98.

${ }^{16}$ See Holland and Skinner, 'Contested Ritual', for a discussion of this point.

${ }^{17}$ James Carrier, 'Occidentalism: The world turned upside-down', American Ethnologist, I9.2 (I992), p. I98.

${ }^{18}$ Gayatri Chakravorty Spivak, The PostColonial Critic: Interviews, strategies and dialogues, Sara Harasym (ed.), (London: Routledge, 1990); Annie Coombes, 'The Recalcitrant Object: Culture contact and the question of hybridity', in Francis Barker, Peter Hulme and Margaret Iversen (eds), Colonial Discourse/Postcolonial Theory (Manchester: Manchester University Press, I994), 89-I14; Benita Parry, 'Resistance Theory/Theorizing Resistance or Two Cheers for Nativism', in Barker, Hulme and Iversen (eds),Colonial Discourse/Postcolonial Theory, 172-96; Nicholas Thomas, Colonialism's Culture: Anthropology, travel and government (Princeton, N.J.: Princeton University Press, i994).

${ }^{19}$ Elizabeth Furniss, In the Spirit of the Pioneers, pp. $174-85,216-28$.

${ }^{20}$ And in keeping with my theoretical argument, these outcomes cannot be determined by an observer's 'reading' of a ritual - they must be ethnographically demonstrated through tracing the application and consequences of cultural representations in a social context. 